\title{
lodine as an alleviator of bromine toxicity in thyroid, liver and kidney of broiler chickens
}

\author{
J. du Toit and N.H. Casey*
}

Department of Animal and Wildlife Sciences, University of Pretoria, Pretoria, South Africa

*Corresponding author at: Department of Animal and Wildlife Science, University of Pretoria, Pretoria, 0001, South Africa. Tel.: +27 124204018; fax: +27 124203290.

\begin{abstract}
The study pursued the hypothesis that bromine $(\mathrm{Br})$ in drinking water at levels $>0.01 \mathrm{mg}$ $\mathrm{Br} / \mathrm{L}$ may have detrimental effects on the liver, kidneys and thyroid and the thyroid hormones $T_{3}$ and $T_{4}$ and that iodine (I) may alleviate the potential hazardous effect of $\mathrm{Br}$. The research was done with mixed Ross broiler chickens over a 42-day post-hatch growth period. The trial design was six treatments, T1: $0 \mathrm{mg} \mathrm{Br} / \mathrm{L}$ and $0 \mathrm{mg} \mathrm{I} / \mathrm{L} ; \mathrm{T} 2: 1 \mathrm{mg} \mathrm{Br} / \mathrm{L}$ and $0 \mathrm{mg} \mathrm{I} / \mathrm{L} ; \mathrm{T} 3: 3 \mathrm{mg} \mathrm{Br} / \mathrm{L}$ and $0 \mathrm{mg} \mathrm{I} / \mathrm{L} ; \mathrm{T} 4: 0 \mathrm{mg} \mathrm{Br} / \mathrm{L}$ and $0.7 \mathrm{mg} \mathrm{I} / \mathrm{L} ; \mathrm{T} 5: 1 \mathrm{mg} \mathrm{Br} / \mathrm{L}$ and $0.7 \mathrm{mg}$ $\mathrm{I} / \mathrm{L}$; and $\mathrm{T} 6: 3 \mathrm{mg} \mathrm{Br} / \mathrm{L}$ and $0.7 \mathrm{mg} \mathrm{I} / \mathrm{L}$ delivered via drinking water and three replicates per treatment with 30 birds per replicate. The effect of $B r$ on $\mathrm{T}_{3}$ and $\mathrm{T}_{4}$ levels overall was nonsignificant, but $T_{3}$ and $T_{4}$ levels decreased between Weeks 4 and 6 with a significant effect at Week 6 on $T_{3}$. Br had an overall effect on the thyroid gland $(P=0.0457)$, liver $(P=0.0025)$ and kidney $(P=0.0032)$, and had accumulated in these three organs. Histopathological assessment showed explicit damage to the livers that received the $\mathrm{Br}$ treatments. lodine $(0.07 \mathrm{mg} / \mathrm{L})$ ameliorated the negative effects of high $\mathrm{Br}(3 \mathrm{mg} / \mathrm{L} \mathrm{Br})$ concentration and ingestion.
\end{abstract}

Keywords: Bromide, lodide, Water, Toxicity, Thyroid hormones

\section{Introduction}

Groundwater in South Africa contains a high range of natural bromide $(\mathrm{Br})$ with recorded values from 0 to $18.4 \mathrm{mg} / \mathrm{L}$ (Casey and Meyer, 2001, 2006). At $18.4 \mathrm{mg} / \mathrm{L} \mathrm{Br}$ the concentration is eight times the level of $2.3 \mathrm{mg} / \mathrm{L}$ recommended by The Safe Drinking Water Committee (1988) for a $70 \mathrm{~kg}$ person drinking $2 \mathrm{~L} /$ day and 92 times the $0.2 \mathrm{mg} / \mathrm{L}$ noted as a maximum Br level in drinking water (El'piner et al., 1972). The current South African Water Quality Guidelines (Second Edition), 1996, set $0.01 \mathrm{mg} / \mathrm{L} \mathrm{Br}$ as the reference value for livestock (Casey and Meyer, 1996). A concentration of a water quality constituent (WQC) that exceeds the reference value is considered to be a potentially hazardous chemical constituent (PHCC). In the instances where $\mathrm{Br}$ exceeds $0.01 \mathrm{mg} / \mathrm{L}, \mathrm{Br}$ is considered to be a PHCC.

The potential toxicity of $\mathrm{Br}$ is well documented. Vaiseman et al. (1986) reported that $96 \%$ of ingested $\mathrm{Br}$ can accumulate in the human body as in livestock, especially within the thyroid gland, liver and kidneys (Jolles, 1966). The accumulated concentrations of $\mathrm{Br}$ in livestock can 
lead to excessive intakes of the mineral by humans through consumable products from livestock as via milk noted by Vreman et al. (1985). Mamabolo et al. (2009) found that broilers over a 42-day growth period exposed to $0.1 \mathrm{mg} / \mathrm{L} \mathrm{Br}$ as $\mathrm{NaBr}$ with Total Dissolved Solid (TDS) < $500 \mathrm{mg} / \mathrm{L}$, accumulated $14.89 \mathrm{mg} / \mathrm{kg}$ DM (dry matter) in the liver, $12.22 \mathrm{mg} / \mathrm{kg}$ DM in the kidney, $20.52 \mathrm{mg} / \mathrm{kg}$ DM in heart muscle, $13.96 \mathrm{mg} / \mathrm{kg} \mathrm{DM}$ in thigh muscle and $7.70 \mathrm{mg} / \mathrm{kg} \mathrm{DM}$ in breast muscle. The $\mathrm{Br}$ accumulation was significantly higher than arsenic (As administered as $\mathrm{As}_{2} \mathrm{O}_{3}$ ) or lead $\left(\mathrm{Pb}\right.$ administered as $\left.\mathrm{Pb}\left(\mathrm{NO}_{3}\right)_{2}\right)$ in the same tissues under the same conditions. Mamabolo et al. (2009) further reported that TDS of $1500 \mathrm{mg} / \mathrm{L}$ increased water intake, but had a positive ameliorating effect on the accumulation of the elements in the tissues. $\mathrm{Br}$ concentrations were still greater than the $\mathrm{As}$ or $\mathrm{Pb}$.

The risk of exposure to $\mathrm{Br}$ levels $>0.01 \mathrm{mg} / \mathrm{L}$ on livestock was reaffirmed (Du Toit and Casey, 2010). Broilers were exposed to balanced combinations of 1 and $3 \mathrm{mg} \mathrm{Br} / \mathrm{L}$ and 0.0 and 0.7 iodine (I) $\mathrm{mg} / \mathrm{L}$ through drinking water (Days 1-42). Treatments administered at 1 and $3 \mathrm{mg}$ $\mathrm{Br} / \mathrm{L}$ or at ingestion rates of 1.59 and $4.44 \mathrm{mg} \mathrm{Br} /$ day affected production parameters significantly. I had an effective ameliorating effect on $\mathrm{Br}$. The negative effect on production parameters may reflect sub-clinical pathological conditions.

Physiological manifestations may occur following the ingestion of $\mathrm{Br}$ over different time periods. The biggest influence is on the production of thyroid gland hormones; the thyroid glands of rats that received high dietary $\mathrm{Br}$ increased significantly (Rauws and Van Logten, 1975). The goitrogenic effect of $\mathrm{Br}$ is further supported by Velický et al. (2004) who recorded marked changes in the morphology of the thyroid gland and reduced iodide accumulation in the thyroid gland, as well as the skin in rats fed a diet containing a high concentration of $\mathrm{Br}$.

Hellerstein et al. (1960) reported that species differences of Br concentrations in tissues were small and that $\mathrm{Br}$ does not accumulate in a particular organ or tissue. Cole and Patrick (1958) and Jolles (1966) on the other hand did report relative proportions of $\mathrm{Br}$ in various organs $2 \mathrm{~h}$ after intraperitoneal administration of 50 microcuries $(\mu \mathrm{c})^{82} \mathrm{Br}$ as $\mathrm{KBr}$. The relative proportions were $1.000 ; 0.536 ; 0.320 ; 0.394 ; 0.131$; and 0.602 for the thyroid gland; kidney; adrenals; liver; brain and blood (Jolles, 1966). Langley (1958) reported that the biological half-life of $\mathrm{Br}$ could be decreased by the administration of surplus I ions.

The study pursued the hypothesis that $\mathrm{Br}$ in drinking water at concentrations exceeding the guideline value $(0.01 \mathrm{mg} \mathrm{Br} / \mathrm{L})$ may have a detrimental effect on the liver, kidneys and thyroid and the thyroid hormones $\mathrm{T}_{3}$ and $\mathrm{T}_{4}$ in broilers over a 42-day growth period, and that $I$ in the drinking water may alleviate the potential hazardous effect of $\mathrm{Br}$.

\section{Materials and methods}

\subsection{Ethics approval}

Procedures for this trial were approved by the University of Pretoria Animal Use and Care Committee (Reference EC080805-032). 


\subsection{Trial design}

The statistical design was a $3 \times 2$ factorial design with three levels of $\operatorname{Br}(0,1$ and $3 \mathrm{mg} / \mathrm{L})$ and two levels of iodine (I) $(0$ and $0.7 \mathrm{mg} / \mathrm{L})$ with three replicates per treatment and thirty Ross broilers of mixed sex per replicate. The duration was 42 days post-hatch. Water intake (WI), weight gain and feed intake (FI) were recorded weekly for each replicate. The treatments were designated

$\mathrm{T} 1: 0 \mathrm{mg} \mathrm{Br} / \mathrm{L}$ and $0 \mathrm{mg} \mathrm{I} / \mathrm{L} ; \mathrm{T} 2: 1 \mathrm{mg} \mathrm{Br} / \mathrm{L}$ and $0 \mathrm{mg} \mathrm{I} / \mathrm{L} ; \mathrm{T} 3: 3 \mathrm{mg} \mathrm{Br} / \mathrm{L}$ and $0 \mathrm{mg} \mathrm{I} / \mathrm{L}$; T4: $0 \mathrm{mg} \mathrm{Br} / \mathrm{L}$ and $0.7 \mathrm{mg} \mathrm{I/L;} \mathrm{T5:} 1 \mathrm{mg} \mathrm{Br} / \mathrm{L}$ and $0.7 \mathrm{mg} \mathrm{I} / \mathrm{L}$; and T6: $3 \mathrm{mg} \mathrm{Br} / \mathrm{L}$ and $0.7 \mathrm{mg} \mathrm{I} / \mathrm{L}$.

\subsection{Animal husbandry}

The housing, management and nutrient composition of the starter (ME/kg DM 11.2), finisher (ME/kg DM 11.4) and post-finisher (11.6 ME/kg DM) broiler diets were as described by du Toit and Casey (2010). Water was delivered from graduated cylinders via bell drinkers for accurate measuring of water intake. The trace element premix contributed $0.001 \mathrm{~g} / \mathrm{kg}$ I to the diets, and $0.0 \mathrm{~g} / \mathrm{kg} \mathrm{Br}$.

\subsection{Treatments}

Selection of 1 and $3 \mathrm{mg} \mathrm{Br} / \mathrm{L}$ was by considering these concentrations of PHCC against the recommended level $0.01 \mathrm{mg} / \mathrm{L}$ (Casey and Meyer, 1996). Since in many rural settings people use the same water source as the livestock the corollary to the opinion of McKee and Wolf (1963) that water safe for human consumption may presumably be used safely by livestock should be considered. The physiological responses of livestock to PHCC may be indicators of the risk to people.

The administration of 0,1 and $3 \mathrm{mg} \mathrm{Br} / \mathrm{L}$ was to verify the recommended levels of $\mathrm{Br}$ at $2.3 \mathrm{mg} / \mathrm{L}$ (The Safe Drinking Water Committee, 1988), $0.2 \mathrm{mg} / \mathrm{L}$ noted as a maximum Br level in drinking water (El'piner et al., 1972) and $0.01 \mathrm{mg} / \mathrm{L}$ (Casey and Meyer, 1996). The possible alleviator effect of I for these high Br levels was tested with $0.7 \mathrm{mg} \mathrm{I/L} \mathrm{since} \mathrm{this}$ concentration is within the Target Water Quality Range for I (0-1 mg/L). Broiler chickens were used as the biological model.

Water from the Pretoria Municipal Source was used. Water samples of the treatments and the control were analysed every week to monitor $\mathrm{Br}$ and I levels by ICP-AES techniques. Separate sample bottles were used for macro- and trace elements during these procedures. The analyses were done against standards at the accredited Institute for Soil, Climate and Water.

The treatments delivered final concentrations of $1 \mathrm{mg} \mathrm{Br} / \mathrm{L}$ and $3 \mathrm{mg} \mathrm{Br} / \mathrm{L}$ as sodium bromide ( $\mathrm{NaBr}$ ), and $0.7 \mathrm{mg} \mathrm{I} / \mathrm{L}$ as potassium iodide (KI). The final concentrations were confirmed by testing the samples at the point of use. 


\subsection{Physiological parameters}

At Days 16 and 42 blood samples were taken from five birds of each replicate before the birds were slaughtered in the conventional way by experienced personnel at the abattoir on the Hatfield Research Farm. The thyroid, liver and kidneys were collected for analysis.

Tissue samples of two chickens from each replicate were taken and stored in polyethylene bags at $-20^{\circ} \mathrm{C}$. These were analysed by standard inductively coupled mass spectrometry (ICP-MS) techniques to determine trace element concentrations.

The thyroid gland, liver and kidney samples were collected from two chickens of each replicate of treatments T3: $3 \mathrm{mg} \mathrm{Br} / \mathrm{L}$ and $0 \mathrm{mg} \mathrm{I} / \mathrm{L}$ and T6: $3 \mathrm{mg} \mathrm{Br} / \mathrm{L}$ and $0.7 \mathrm{mg} \mathrm{I} / \mathrm{L}$ for histopathological assessments by a clinical pathologist. The samples were placed in buffered formalin. The tissues were block selected and processed in an automated histological tissue processor before specific wax blocks were produced. Sections of $5 \mu \mathrm{m}$ were cut on a microtome and the tissue slides were stained with Haematoxylin and Eosin staining in an automated histological stainer. The histopathological assessments were graded as no observable organ damage $(-)$, mild organ damage $(1+)$, moderate organ damage $(2+)$ and severe organ damage $(3+)$, where damage is a deviation from normal morphology.

The serum of blood samples from two chickens of each replicate was analysed for free $T_{3}$ and $\mathrm{T}_{4}$ concentration by Chemiluminescence Enzyme Immunoassay (CLIA) (Kricka et al., 1987).

In the $T_{3}$ CLIA, as explained by Rongen et al. (1994), a certain amount of anti- $T_{3}$ antibody was coated on micro titer wells. A measured amount of chicken serum and a constant amount of $\mathrm{T}_{3}$ conjugated with horseradish peroxidase were added to the micro titer wells. During incubation, $T_{3}$ in the samples and conjugated $T_{3}$ competed for the limited binding sites on the anti- $T_{3}$ antibody of the wells. After $60 \mathrm{~min}$ of incubation at room temperature, the wells were washed 5 times by wash solution to remove unbound $T_{3}$ conjugate. $A$ solution of chemiluminescent substrate was then added and relative light units in a Luminometer were read. The intensity of the emitting light was proportional to the amount of enzyme present and was inversely related to the amount of unlabelled $T_{3}$ in the sample. By reference to a series of $T_{3}$ standards assayed in the same way, the concentration of $T_{3}$ in the unknown sample was quantified (Rongen et al., 1994). The precise method for $\mathrm{T}_{3}$ was repeated for $\mathrm{T}_{4}$.

\subsection{Statistical evaluation}

The GLM procedure of the SAS (Statistical Analyses System ${ }^{\circledR}$ ) software system was used in the statistical analysis. The significance of differences between treatments and exposure periods was established by means of the Fisher's test at $P<0.05$. 


\section{Results}

$\mathrm{T}_{4}$ hormone levels between treatments within Week 4 and Week 6 did not differ significantly, although the $3 \mathrm{mg} \mathrm{Br} / \mathrm{L}$ inclusion levels (Treatments 2 and 5) showed slightly lower $\mathrm{T}_{4}$ hormone levels (Table 1 ).

Table 1. Average $\mathrm{T}_{4}$ hormone levels (pmol/L) (means and SD) of broilers with the different bromine ( $\mathrm{Br}$ ), iodine (I) levels (mg/L) in treatments T1 to T6 compared within weeks 4 and 6.

\begin{tabular}{|c|c|c|c|c|c|c|c|c|}
\hline Week & $\begin{array}{l}\text { Treatn } \\
\text { T1 O B }\end{array}$ & T2 1 B & T3 3 & $\mathrm{~T} 40 \mathrm{~B}$ & T5 $1 \mathrm{~B}$ & T6 $3 \mathrm{~B}$ & Mean & P-value \\
\hline 4 & $\begin{array}{l}6.27 \\
(0.89)\end{array}$ & $\begin{array}{l}6.38 \\
(1.54)\end{array}$ & $\begin{array}{l}5.42 \\
(0.28)\end{array}$ & $\begin{array}{l}5.52 \\
(0.40)\end{array}$ & $\begin{array}{l}5.77 \\
(0.73)\end{array}$ & $\begin{array}{l}6.50 \\
(0.60)\end{array}$ & $\begin{array}{l}5.98 \\
(0.91)\end{array}$ & 0.7412 \\
\hline 6 & $\begin{array}{l}6.00 \\
(1.09)\end{array}$ & $\begin{array}{l}5.59 \\
(0.62)\end{array}$ & $\begin{array}{l}5.29 \\
(0.33)\end{array}$ & $\begin{array}{l}5.89 \\
(0.75)\end{array}$ & $\begin{array}{l}5.80 \\
(0.24)\end{array}$ & $\begin{array}{l}5.10 \\
(0.00)\end{array}$ & $\begin{array}{l}5.61 \\
(0.63)\end{array}$ & 0.5360 \\
\hline
\end{tabular}

Differences determined at $\mathrm{P}<0.05$ according to the Fischer's Test.

The treatments had no effect on $T_{3}$ hormone at Week $4(P=0.2503)$, but the effect became significant at Week $6(P=0.0010)$. Within week 6 , the increasing level of $B r(T 2$ to T3) significantly reduced $T_{3}$ hormone levels. I $(P=0.0273)$, irrespective of $B r$, as well as the interaction between I and $\mathrm{Br}(\mathrm{P}=0.0019)$ had an ameliorating effect on the $\mathrm{T}_{3}$ hormone levels (T6 compared with T3) (Table 2).

Table 2. Average $T_{3}$ hormone levels (pmol/L) (means and SD) of broilers with the different bromine $(\mathrm{Br})$ and iodine (I) levels (mg/L) in treatments T1 to T6 compared within weeks 4 and 6.

\begin{tabular}{|c|c|c|c|c|c|c|c|c|}
\hline Week & $\begin{array}{l}\text { Treatn } \\
\text { T1 } 0 \text { B }\end{array}$ & T2 1 B & T3 3 B & $\mathrm{T} 40 \mathrm{~B}$ & T5 $1 \mathrm{~B}$ & T6 $3 \mathrm{~B}$ & Mean & P-value \\
\hline 4 & $\begin{array}{l}3.33 \\
(0.94)\end{array}$ & $\begin{array}{l}3.55 \\
(0.74)\end{array}$ & $\begin{array}{l}4.60 \\
(1.53)\end{array}$ & $\begin{array}{l}3.27 \\
(0.32)\end{array}$ & $\begin{array}{l}4.10 \\
(0.30)\end{array}$ & $\begin{array}{l}3.37 \\
(1.46)\end{array}$ & $\begin{array}{l}3.70 \\
(0.89)\end{array}$ & 0.2503 \\
\hline 6 & $\begin{array}{l}2.20^{b} \\
(0.30)\end{array}$ & $\begin{array}{l}2.78^{a} \\
(0.50)\end{array}$ & $\begin{array}{l}2.17^{b} \\
(0.16)\end{array}$ & $\begin{array}{l}2.07^{b} \\
(0.35)\end{array}$ & $\begin{array}{l}2.55^{a} \\
(0.28)\end{array}$ & $\begin{array}{l}2.53^{a} \\
(0.33)\end{array}$ & $\begin{array}{l}2.38 \\
(0.18)\end{array}$ & 0.0010 \\
\hline
\end{tabular}

${ }^{a b}$ Row means with different superscripts within weeks differ $(P<0.05)$ according to the Fischer's Test.

$\mathrm{Br}$ treatments affected the $\mathrm{Br}$ content of the thyroid gland, $(P=0.0457)$, liver $(P=0.0025)$ and kidney $(P=0.0032)$. Br treatments affected the I content of the liver $(P=0.0235)$ and kidney $(P=0.0141)$, but not the I content of the thyroid gland $(P=0.3950) . T 4(0.0 \mathrm{mg} / \mathrm{L}$ $\mathrm{Br}+0.07 \mathrm{mg} / \mathrm{L} \mathrm{I})$ recorded the lowest $\mathrm{Br}$ levels in the thyroid gland $(P=0.0467)$, liver $(P=0.0025)$ and kidney $(P=0.0032)$ and $\mathrm{T} 3(3 \mathrm{mg} / \mathrm{L} \mathrm{Br}+0 \mathrm{mg} / \mathrm{LI})$ recorded the highest levels of $\mathrm{Br}$ within the three organs (Tables 3, 4 and 5). The $\mathrm{Br}$ accumulated within $\mathrm{T} 6$ ( $3 \mathrm{mg}$ $\mathrm{Br} / \mathrm{L}$ and $0.7 \mathrm{mg} \mathrm{I} / \mathrm{L}$ ) was less than the $\mathrm{Br}$ content accumulated within $\mathrm{T} 3(3 \mathrm{mg} / \mathrm{L} \mathrm{Br}+0 \mathrm{mg} / \mathrm{L}$ I). Although the $\mathrm{Br}$ treated groups reported the lowest I accumulation within the thyroid gland, the differences were not significant (Tables 3, 4 and 5). A comparison between the organs shows that the kidney accumulated more $\mathrm{Br}$ than the thyroid gland or liver. 
Table 3. Average bromine ( $\mathrm{Br}$ ) and iodine (I) (mg/kg DM) (means and SD) in the thyroid gland of broilers exposed to different bromine $(\mathrm{Br})$ and iodine $(\mathrm{I})$ levels $(\mathrm{mg} / \mathrm{L})$ in treatments $\mathrm{T} 1$ to $\mathrm{T} 6$ over a 42-day growth period.

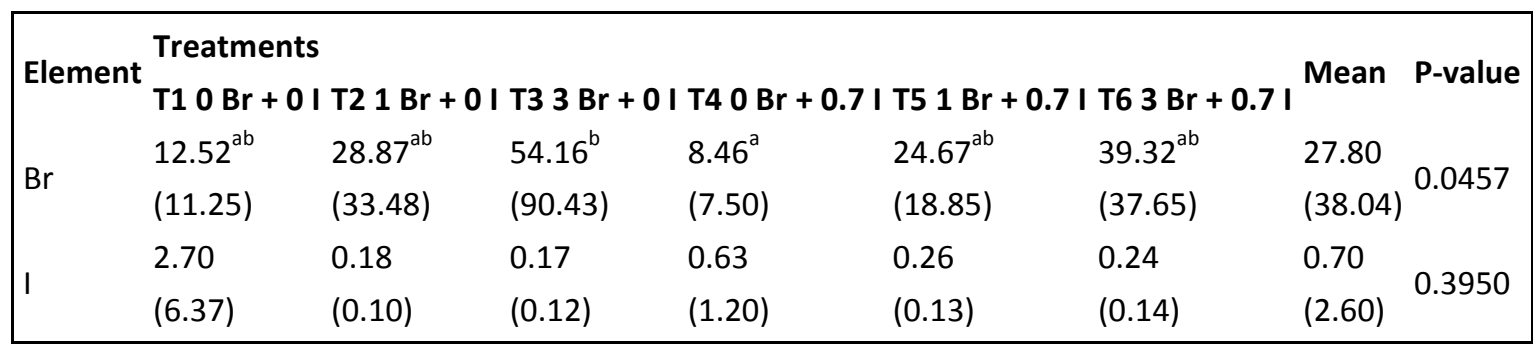

${ }^{a b}$ Row means with different superscripts differ $(P<0.05)$ according to the Fischer's Test.

Table 4. Average bromine ( $\mathrm{Br}$ ) and iodine (I) (mg/kg DM) (means and SD) in the liver of broilers exposed to different bromine $(\mathrm{Br})$ and iodine $(\mathrm{I})$ levels $(\mathrm{mg} / \mathrm{L})$ in treatments $\mathrm{T} 1$ to $\mathrm{T} 6$ over a 42-day growth period.

\begin{tabular}{|c|c|c|c|c|c|c|c|c|}
\hline Element & $\begin{array}{l}\text { Treatme } \\
\text { T1 } 0 \mathrm{Br}\end{array}$ & $\mathrm{T} 21 \mathrm{Br}+$ & T3 $3 \mathrm{Br}+$ & $\mathrm{T} 40 \mathrm{Br}$ & T5 $1 \mathrm{Br}$ & $\mathrm{T} 63 \mathrm{Br}+$ & Mean & P-value \\
\hline $\mathrm{Br}$ & $\begin{array}{l}12.04^{\mathrm{ab}} \\
(11.92)\end{array}$ & $\begin{array}{l}32.11^{a b c} \\
(27.56)\end{array}$ & $\begin{array}{l}95.59^{c} \\
(128.41)\end{array}$ & $\begin{array}{l}6.18^{b} \\
(5.36)\end{array}$ & $\begin{array}{l}17.75^{\mathrm{ab}} \\
(20.68)\end{array}$ & $\begin{array}{l}77.58^{\mathrm{ac}} \\
(104.19)\end{array}$ & $\begin{array}{l}40.21 \\
(56.57)\end{array}$ & 0.0025 \\
\hline I & $\begin{array}{l}0.27 \\
(0.15)\end{array}$ & $\begin{array}{l}0.35 \\
(0.18)\end{array}$ & $\begin{array}{l}0.28 \\
(0.14)\end{array}$ & $\begin{array}{l}0.26 \\
(0.16)\end{array}$ & $\begin{array}{l}0.33 \\
(0.14)\end{array}$ & $\begin{array}{l}0.21 \\
(0.12)\end{array}$ & $\begin{array}{l}0.28 \\
(0.13)\end{array}$ & 0.0235 \\
\hline
\end{tabular}

${ }^{a b c}$ Row means with different superscripts differ $(P<0.05)$ according to the Fischer's Test.

Table 5. Average bromine ( $\mathrm{Br}$ ) and iodine (I) (mg/kg DM) (means and SD) in the kidneys of broilers exposed to different bromine $(\mathrm{Br})$ and iodine $(\mathrm{I})$ levels $(\mathrm{mg} / \mathrm{L})$ in treatments $\mathrm{T} 1$ to $\mathrm{T} 6$ over a 42-day growth period.

\begin{tabular}{|c|c|c|c|c|c|c|c|c|}
\hline Element & \multicolumn{6}{|c|}{ Treatments } & Means & P-value \\
\hline \multirow{2}{*}{$\mathrm{Br}$} & $32.08^{a}$ & $102.86^{\mathrm{ab}}$ & $210.05^{b}$ & $22.46^{a}$ & $71.85^{\mathrm{ab}}$ & $161.02^{\mathrm{ab}}$ & 100.05 & 0.0032 \\
\hline & (40.69) & (108.87) & (320.61) & $(22.37)$ & $(65.25)$ & (196.65) & \multicolumn{2}{|l|}{ (130.12) } \\
\hline \multirow{2}{*}{ | } & $0.30^{\mathrm{ab}}$ & $0.42^{\mathrm{ab}}$ & $0.26^{b}$ & $0.28^{b}$ & $0.45^{\mathrm{a}}$ & $0.29^{\mathrm{ab}}$ & 0.33 & 0.0141 \\
\hline & (0.19) & $(0.22)$ & $(0.16)$ & $(0.13)$ & $(0.10)$ & $(0.16)$ & $(0.14)$ & \\
\hline
\end{tabular}

${ }^{a b}$ Row means with different superscripts differ $(P<0.05)$ according to the Fischer's Test.

The accumulated I levels were the highest in the thyroid gland and less in the liver and kidney.

The histopathology assessments (Tables 6 and 7) indicated a difference between the liver morphology of T1 compared to the livers from both T6 and T3. The hepatocellular hypertrophy appeared to be most severe in T3 and less prominent among T6. Vacuolar degeneration was due to swelling of the intracytoplasmic endoplasmic reticulum and may have followed on different forms of damage to the hepatocytes. It tended to show the same pattern as found in hepatocellular hypertrophy recorded in the liver sections. Fatty change, characterized by round fat droplets within the cytoplasm, did not show any specific pattern among the treatment groups or the control birds. The kidney and thyroid gland appeared 
similar without any specific pathological changes among the treatment groups or in the control birds.

Table 6. Histopathological lesions in liver sections from broilers exposed (mg/L) to $\mathrm{T} 1(0 \mathrm{Br}+0 \mathrm{I}), \mathrm{T} 3(3 \mathrm{Br}+0 \mathrm{I})$ and $\mathrm{T} 6(3 \mathrm{Br}+0.7 \mathrm{I})$ at Week 4 of the growth period.

\begin{tabular}{|c|c|c|c|c|c|c|c|c|c|}
\hline \multirow{3}{*}{ Hepatic lesion } & \multicolumn{3}{|c|}{$\mathrm{T} 10 \mathrm{Br}+0 \mathrm{I}$} & \multicolumn{3}{|c|}{$\mathrm{T} 33 \mathrm{Br}+0 \mathrm{I}$} & \multicolumn{3}{|c|}{ T6 $3 \mathrm{Br}+0.7 \mathrm{I}$} \\
\hline & Sample & Sample & Sample & Sample & Sample & Sample & Sample & Sample & Sample \\
\hline & 1 & 2 & 3 & 1 & 2 & 3 & 1 & 2 & 3 \\
\hline $\begin{array}{l}\text { Hepatocellular } \\
\text { hypertrophy }\end{array}$ & - & - & - & $2+$ & $3+$ & $1+$ & $1+$ & - & $1+$ \\
\hline Vacuolar degeneration & - & - & - & $3+$ & $3+$ & $2+$ & $1+$ & $1+$ & $1+$ \\
\hline $\begin{array}{l}\text { Fatty change } \\
\text { intracytoplasmic }\end{array}$ & - & - & - & - & - & - & - & - & $1+$ \\
\hline
\end{tabular}

- No observable organ damage; ${ }^{1+}$ mild organ damage; ${ }^{2+}$ moderate organ damage; ${ }^{3+}$ severe organ damage.

Table 7. Histopathological lesions in liver sections from broilers exposed $(\mathrm{mg} / \mathrm{L})$ to $\mathrm{T} 1(0 \mathrm{Br}+0 \mathrm{I}), \mathrm{T} 3(3 \mathrm{Br}+0 \mathrm{I})$ and $\mathrm{T} 6(3 \mathrm{Br}+0.07 \mathrm{I})$ at Week 6 of the growth period.

\begin{tabular}{|lllllllllll}
\hline & T1 & & \multicolumn{3}{c}{ T3 } & \multicolumn{3}{c}{ T6 } \\
Hepatic lesion & Sample & Sample & Sample & Sample & Sample & Sample & Sample & Sample & Sample \\
Hepatocellular & $\mathbf{1}$ & $\mathbf{2}$ & $\mathbf{3}$ & $\mathbf{1}$ & $\mathbf{2}$ & $\mathbf{3}$ & $\mathbf{1}$ & $\mathbf{2}$ & $\mathbf{3}$ \\
$\begin{array}{l}\mathrm{l} \\
\text { hypertrophy }\end{array}$ & - & - & - & $2+$ & $3+$ & $2+$ & - & $1+$ & - \\
$\begin{array}{l}\text { Vacuolar degeneration } \\
\text { Fatty change }\end{array}$ & - & - & - & $2+$ & $3+$ & $2+$ & - & $1+$ & - \\
intracytoplasmic & - & - & - & $3+$ & $1+$ & $1+$ & $1+$ & $1+$ & $1+$ \\
\hline
\end{tabular}

- No observable organ damage; ${ }^{1+}$ mild organ damage; ${ }^{2+}$ moderate organ damage; ${ }^{3+}$ severe organ damage.

A comparison of the results of Weeks 4 and 6 (Table 6 ) shows that the damage due to T6 is similar at both Week 4 and Week 6 (Table 7). T6 had no observable organ damage at week 4 for intracytoplasmic fatty change, but at Week 6 severe to mild organ damage was recorded.

\section{Discussion}

Ingestion rates need to be calculated when water with a WQC that is a PHCC such as Br is encountered. This is important as it is the actual amount of PHCC ingested that is relevant, and not the concentration in the water alone. The cumulative intake of $\mathrm{Br}$ (mg/bird/day) over the 42-day growth period was 1.591 (T2), 4.442 (T3), 0.093 (T4), 1.567 (T5) and 4.618 (T6) as published by du Toit and Casey (2010).

The results reiterate the accumulation of levels of $\mathrm{Br}$ in tissues (heart, thyroid gland, liver, thigh and breast muscle) of poultry exposed to drinking water with $\mathrm{Br}$ content $>0.01 \mathrm{mg} / \mathrm{L}$ that Casey and Meyer (2006) recorded in chickens raised under extensive, free-range 
production conditions where the chickens had access to groundwater with high $\mathrm{Br}$ content (>0.01 mg/L). However, they had not investigated the specific effect of $\mathrm{Br}$ on the thyroid hormones $\mathrm{T}_{3}$ and $\mathrm{T}_{4}$. The results imply that breast and thigh muscle cannot be excluded as a risk of transmitting $\mathrm{Br}$ to consumers. Concerns are raised in particular where in rural production systems through slower growth of chickens and longer exposure and high total ingestion of $\mathrm{Br}$ (including free-ranging layers) and subsequent accumulation in tissues, $\mathrm{Br}$ may be carried over to people via the meat and organs. The risk is increased further when people and their chickens drink water from the same groundwater source that contains high levels of $\mathrm{Br}$.

Jolles (1966) reported that after $2 \mathrm{~h}$ of $\mathrm{Br}$ administration the proportional amounts of $\mathrm{Br}$ accumulated within the thyroid gland was 1 , for the kidney it was 0.5 and the liver 0.4 . This indicates that the highest accumulation of $\mathrm{Br}$ should have occurred within the thyroid gland, but in this trial the highest accumulation occurred within the kidney. On the other hand, Abelin and Poretti (1952), Bosshardt et al. (1956), Huff et al. (1956), Mack and Shipley (1952) and Winnek and Smith (1937) could demonstrate no preferential uptake by the thyroid gland. Cole and Patrick (1958) measured the kidney and intestines as the most active organs to have taken up ${ }^{82} \mathrm{Br}$ after a 2 hour intraperitoneal administration. Hellerstein et al. (1960) reported that $\mathrm{Br}$ accumulation does not occur in any particular organ or tissue. Abelin and Poretti (1952) and Winnek and Smith (1937) showed through chemical analyses that supplemented dietary $\mathrm{Br}$ increased $\mathrm{Br}$ levels in the blood, liver, kidney, adrenals, muscle, spleen and the brain. Golomb (1999) also reported that because of slow excretion of bromide through the kidneys, $\mathrm{Br}$ may accumulate in the body when continuously ingested. Masoud et al. (1973) reported acute renal failure cases leading to death by a direct nephrotoxic effect of the bromate ion. These reports emphasize the potential problems arising with $\mathrm{Br}$ in water at concentrations $>0.01 \mathrm{mg} / \mathrm{L}$.

The long half-life of bromide is 14 to $94 \mathrm{~h}$ for the thyroid gland, 88 to $235 \mathrm{~h}$ for the liver and 22 to $197 \mathrm{~h}$ for the whole body (Pavelka et al., 1999). Frances et al. (2003) reported a 10-day half-life elimination period for $\mathrm{Br}$ in the blood. The prolonged half-life in the thyroid gland, liver, whole body and blood indicate why the vast quantities of $\mathrm{Br}$ accumulation were seen in these three organs. The I concentrations within all three of the tested organs decreased as $\mathrm{Br}$ treatments increased, but were non-significant. The I concentrations for the kidney were less than for the other two organs, indicating the ameliorating effect of I on the kidney. This observation can be explained by Pavelka et al. (2002) as high levels of Br intake influence the I metabolism of the animal by increasing the iodide excretion by the kidneys. Fortunately for a 42-day production period I did alleviate the effect of $\mathrm{Br}$ not to the expense of $I$. The I concentrations were the highest for the thyroid gland and less for the liver and kidney. This is a typical observation as reported by Perlman et al. (1941), as the thyroid gland has 100 times the ability of the liver and the kidney to retain I.

The histopathological assessment established explicit damage to the livers that received the elevated $\mathrm{Br}$ treatments; severe damage in the form of hepatocellular hypertrophy and vacuolar degeneration were reported. It was also clear that the alleviator element (I) compensated for the damage caused by $\mathrm{Br}$, by comparing the mild damage in $\mathrm{T} 3$ with the more severe damage in the T6. A longer exposure period can possibly indicate significant I reduction within the thyroid gland, liver and kidney. At 6 weeks of age the damage had 
augmented and a new symptom, intracytoplasmic fatty change was reported for both of the treatment groups, where the elevated treatment group was moderately damaged and the alleviator group mildly damaged. It was clearly stated in the histopathology report that the factor of time did play a role in the degeneration of the histopathology of the organs receiving high $\mathrm{Br}$ treatments.

Although the highest $\mathrm{Br}$ concentration was found to be within the kidney, the liver was most severely damaged according to the histopathology report. A longer exposure period might have indicated histopathological severity to the thyroid gland and the kidney. A study by Velický et al. (2004) noted the adverse effect $\mathrm{Br}$ had on the ultra-structure of rat thyroid glands. The administration of 10,50 and $100 \mathrm{mg} \mathrm{Br} / \mathrm{L}$ for 16 or 60 days resulted in marked hypertrophy and hyperplasia of the thyroid gland, micro follicular rearrangement and lower colloid volume. A sub-clinical condition due to $\mathrm{Br}$ could have had a detrimental effect on the chickens as shown by the effect on production parameters (Du Toit and Casey, 2010) that might be observed clinically after a longer period of exposure. The concern with a subclinical condition is that the lack of observable adverse effects can create the impression that the water has no possible hazardous effect, i.e. no PHCC. The same obscured risk would apply to animal products for human consumption as very high levels of $\mathrm{Br}$ accumulated within the three observed organs, the thyroid gland, liver and kidney.

\section{Conclusions}

The results obtained in this study indicate that the current guideline level of $0.01 \mathrm{mg} / \mathrm{L} \mathrm{Br}$ in drinking water may not be too restrictive. The trial confirmed that concentrations of the PHCC $(\mathrm{Br})$ in the drinking water of broilers can accumulate to concentrations that exceed a maximum acceptable concentration of $1 \mathrm{mg} \mathrm{Br} / \mathrm{L}$ in animal tissues used for human consumption, regardless of a short exposure period. Explicit histopathological damage was caused in the livers of broilers that received the elevated $\mathrm{Br}$ treatments of 1 and $3 \mathrm{mg} \mathrm{Br} / \mathrm{L}$, or the equivalent ingestion levels of 1.59 and $4.44 \mathrm{mg} \mathrm{Br} / \mathrm{L}$ per bird per day. It is shown that I has a potential ameliorative effect on $\mathrm{Br}$ toxicity in broilers.

\section{Acknowledgements}

R.J. Coertze and H.T. Groeneveld, Faculty of Natural and Agricultural Sciences, University of Pretoria, for assistance with the statistical analyses.

W.S. Botha, clinical pathologist, IDEXX Laboratories (Pty) Ltd, Pretoria, South Africa, for assistance with the pathological evaluation of the kidneys and liver.

Lancet Laboratories, Pretorius, South Africa, for assistance with measuring the levels (pmol/L) of the thyroid hormones $\mathrm{T}_{3}$ and $\mathrm{T}_{4}$ in blood serum.

The Agricultural Research Council, Institute for Soil, Climate and Water, for assistance with the analyses of water. 


\section{References}

Abelin, J., Poretti, G., 1952. The distribution of bromine in the body. Helv. Physiol. Pharmacol. Acta 10 (C7-C9), 91.

Bosshardt, K.D., Huff, J.W., Barnes, R.H., 1956. Effect of bromine on chick growth. Proc. Soc. Exp. Biol. Med. 92, 219-221.

Casey, N.H., Meyer, J.A., 1996. South African Water Quality Guidelines, Second Edition. Agricultural Use: Section 4.4, Water Quality Guidelines for Livestock Watering, Volume 5. Department of Water Affairs and Forestry, 0-7988-5343-3.

Casey, N.H., Meyer, J.A., 2001. An extension to and further refinement of water quality guideline index system for livestock watering. Rural communal livestock production system and wildlife production system. WRC Report No 857/1/01, Volume 1.

Casey, N.H., Meyer, J.A., 2006. The application of risk assessment modelling in groundwater for humans and livestock in rural, communal systems. WRC Report No 1175/1/06. ISBN: 1 770054677.

Cole, B.T., Patrick, H., 1958. Tissue uptake \& excretion of bromine-82 by rats. Arch. Biochem. Biophys. 74 (2), 357-361.

Du Toit, J., Casey, N.H., 2010. Effect of bromine and iodine in drinking water on production parameters of broilers. S. Afr. J. Anim. Sci. 40 (4), 301-310.

El'piner, L.I., Shafirov, Y.B., Khovakh, I.M., Shub, O.A., Gurvich, I.A., 1972. Hygienic substantiation of permissible content of bromine in drinking water. Gig. Sanit. 37, 13-17.

Frances, C., Hoizey, G., Lamiable, D., Millart, H., Trenque, T., 2003. Bromism from daily over intake of bromide salt. Clin. Toxicol. 41 (2), 181-183.

Golomb, B.A., 1999. A review of the scientific literature as it pertains to Gulf War illnesses. Pyridostigmine bromide: DC RAND, Vol. 2, pp. 131-142. Chapter 10.

Hellerstein, S., Kaiser, C., Darrow, D.D., Darrow, D.C., 1960. The distribution of bromide and chloride in the body. J. Clin. Invest. 39, 282-287.

Huff, J.W., Bosshardt, D.K., Miller, C.P., Barnes, R.H., 1956. A nutritional requirement for bromine. Proc. Soc. Exp. Biol. Med. 92, 216-219.

Jolles, Z.E., 1966. Bromine and its Compounds. Academic Press, Toronto. Canada, pp. 487497.

Kricka, L.J., Thorpe, G.H.G., Stott, R.A.W., 1987. Enhanced chemiluminescence enzyme immunoassay. Pure Appl. Chem. 59 (5), 651-654. 
Langley, C.A., 1958. Bromide excretion as effected by chloride administration. J. Am. Pharm. Assoc. 47, 467-471.

Mack, J.F., Shipley, R.A., 1952. Comparative uptake of $\mathrm{Br} 82$ by the hypophysis and other tissue. Proc. Soc. Exp. Biol. Med. 80 (1), 18-20.

Mamabolo, M.C., Casey, N.H., Meyer, J.A., 2009. Effects of total dissolved solids on the accumulation of $\mathrm{Br}$, As and $\mathrm{Pb}$ from drinking water in tissues of selected organs in broilers. $\mathrm{S}$. Afr. J. Anim. Sci. 39 (1), 169-172.

Masoud, A.N., Elder, J.T., Czerwinski, A.L., 1973. Chemistry and pharmacology of common acute poisoning in children. Paediatrician 2, 2-37.

McKee, J.E., Wolf, H.W., 1963. 2nd Edition. Water Quality Criteria, 112. The Resources agency of California State Water Resources Control board, California, p. 148.

Pavelka, S., Babicky, A., Vobecky, M., Lener, J., Svandova, E., 1999. Bromide kinetics and distribution in the rat. Biol. Trace Elem. Res. 76, 57-66.

Pavelka, S., Babicky, A., Vobecky, M., Lener, J., 2002. Impact of high bromide intake in the rat dam on iodine transfer to the sucklings. Food Chem. Toxicol. 40 (7), 1041-1045.

Perlman, I., Chaikoff, I.L., Morton, M.E., 1941. Radioactive iodine as an indicator of the metabolism of lodine. J. Biol. Chem. 139, 433-447.

Rauws, A.G., Van Logten, M.J., 1975. The influence of dietary chloride on the bromide excretion in the rat. Toxicology 3, 29-32.

Rongen, H.A., Hoetelmans, R.M., Bult, A., Bennekom, W.P., 1994. Chemiluminescence and immunoassays. J. Pharm. Biomed. Anal. 12 (4), 433-462.

The Safe Drinking Water Committee, 1988. Drinking Water and Health, Volume 3. National Academy Sciences, Washington D.C.. Chapter 4, 181-187, 215-225.

Vaiseman, N., Koren, G., Pencharz, P., 1986. Pharmacokinetics of oral and intravenous bromide in normal volunteers. J. Toxicol. Clin. Toxicol. 24 (5), 403-413.

Velický, J., Titlbach, M., Lojda, Z., Dušková, J., Vobecký, M., Raška, I., 2004. The effect of bromide on the ultrastructure of rat thyrocytes. Ann. Anat. 186, 209-216.

Vreman, K., Roos, A.H., Tuinstra, G.M., 1985. The excretion of inorganic bromide into milk of dairy cows after oral administration. Neth. Milk Dairy J. 39, 173-181.

Winnek, P.S., Smith, A.H., 1937. The determination of bromine in biological substances. J. Biol. Chem. 119, 93-101. 